$I-10941$

\title{
CONCEPTUAL DESIGN OF THE HIGH-FLUX VTA-2 TEST ASSEMBLY FOR FMIT
}

\section{Hanford Engineering Development Laboratory}
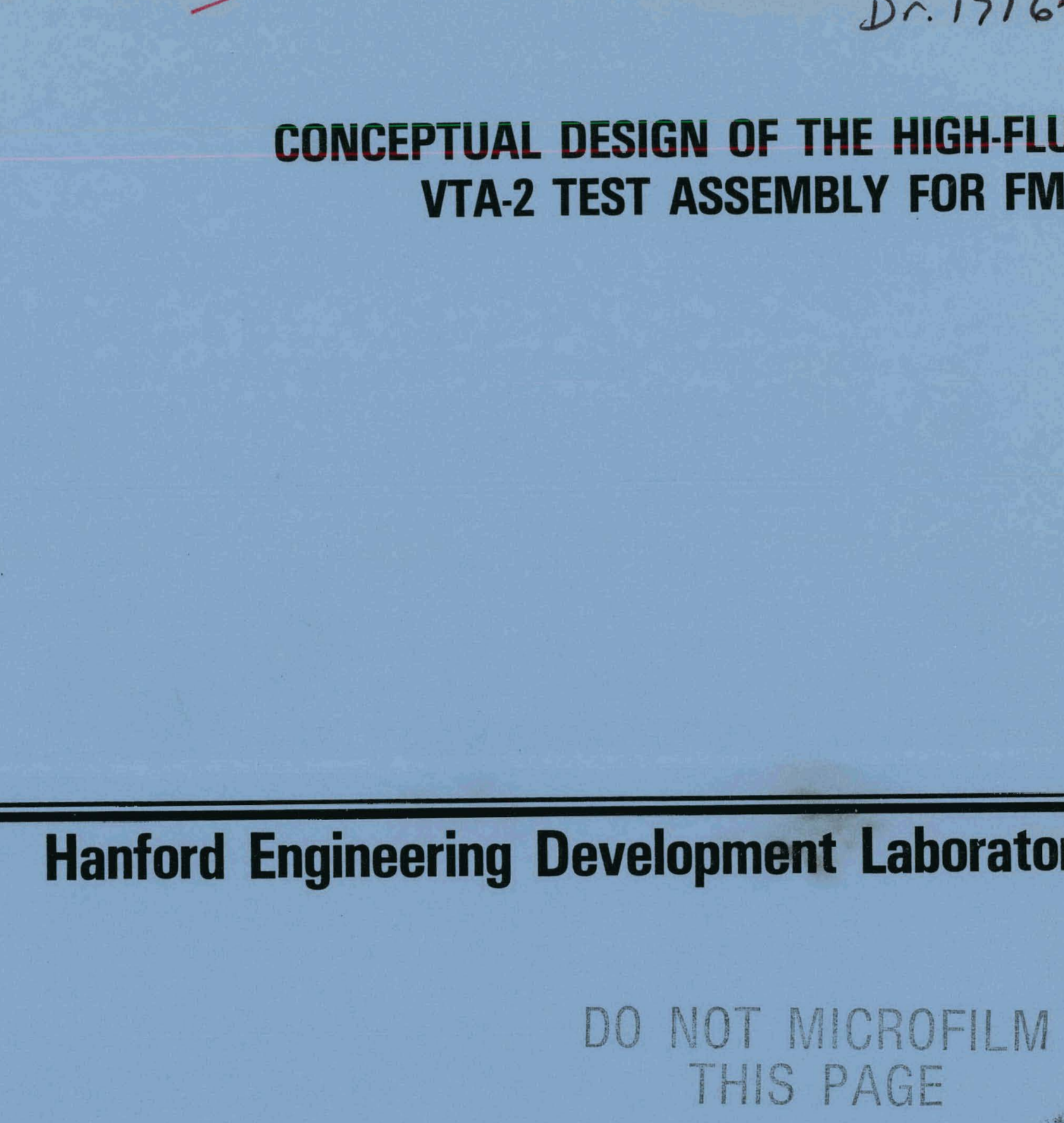

HANFORD ENGINEERING DEVELOPMENT LABORATORY

Operated by Westinghouse Hanford Company

P.O. Box 1970 Richland, WA 99352

A Subsidiary of Westinghouse Electric Corporation

Prepared for the U.S. Department of Energy Office of Energy Research Office of Fusion Energy under Contract No. DE-AC06-76FF02170 B\&R No. AT-20-40-41 


\section{DISCLAIMER}

This report was prepared as an account of work sponsored by an agency of the United States Government. Neither the United States Government nor any agency Thereof, nor any of their employees, makes any warranty, express or implied, or assumes any legal liability or responsibility for the accuracy, completeness, or usefulness of any information, apparatus, product, or process disclosed, or represents that its use would not infringe privately owned rights. Reference herein to any specific commercial product, process, or service by trade name, trademark, manufacturer, or otherwise does not necessarily constitute or imply its endorsement, recommendation, or favoring by the United States Government or any agency thereof. The views and opinions of authors expressed herein do not necessarily state or reflect those of the United States Government or any agency thereof. 


\section{DISCLAIMER}

Portions of this document may be illegible in electronic image products. Images are produced from the best available original document. 


\section{The following pages are an exact representation of what is in the original document folder.}




\section{DO NOT MICROFILM THIS PAGE.}

\section{NOTICE}

This report was prepared as an account of work sponsored by an agency of the United States Government. Neither the United States Government nor any agency thereof, nor any of their employees, nor any of their contractors, subcontractors or their employees, makes any warranty, express or implied, or assumes any legal liability or responsibility for the accuracy, completeness, or any third party's use or the results of such use of any information, apparatus, product, or process disclosed, or represents that its use would not infringe privately owned rights. Reference herein to any specific commercial product, process, or service by trade name, trademark, manufacturer, or otherwise, does not necessarily constitute or imply its endorsement, recommendation, or favoring by the United States Government or any agency thereof or its contractors or subcontractors.

Available from the National Technical Information Service, U. S. Department

of Commerce, Springfield, Virginia 22161

NTIS price codes

Printed Copy: $A 03$

Microfiche copy: A01 


\section{CONCEPTUAL DESIGN OF THE HIGH-FLUX VTA-2 TEST ASSEMBLY FOR FMIT.}

\section{DISCLAIMER}

This report was prepared as an account of work sponsored by an agency of the United States Government. Neither the United States Government nor any agency thereof, nor any of their employees, makes any warranty, express or implied, or assumes any legal liability or responsibility for the accuracy, completeness, or usefulness of any information, apparatus, product, or process disclosed, or represents that its use would not infringe privately owned rights. Reference herein to any specific commercial product, process, or service by trade name, trademark, manufacturer, or otherwise does not necessarily constitute or imply its endorsement, recommendation, or favoring by the United States Government or any agency thereof. The views and opinions of authors expressed herein do not necessarily state or reflect those of the United States Government or any agency thereof.

\section{Hanford Engineering Development Laboratory \\ M.A. Vogel \\ August 1983}

HANFORD ENGINEERING DEVELOPMENT LABORATORY Operated by Westinghouse Hanford Company

P.O. Box 1970 Richland, WA 99352 A Subsidiary of Westinghouse Electric Corporation Prepared for the U.S. Department of Energy

Office of Energy Research

Office of Fusion Energy under Contract No. DE-ACO6-76FF02170 
THIS PAGE

\section{WAS INTENTIONALLY LEFT BLANK}


HEDL-TME 83-19

UC-20

\section{CONCEPTUAL DESIGN OF THE HIGH-FLUX}

VTA-2 TEST ASSEMBLY FOR FMIT

M. A. Voge 1

\section{ABSTRACT}

This report describes the conceptual design of the test module for the high neutron flux vertical test assembly (VTA-2). The description emphasizes the thermal control systems available for monitoring test specimen temperatures at any desired temperature within the range of 1000-6500C. VTA-2 will be located in the Fusion Materials Irradiation Test Facility (FMIT) test cell directly behind VTA-1. 


\section{CONTENTS}

Page

Abstract $\quad$ iii

Figures vi

Tables vi

1.0 SUMMARY AND CONCLUSIONS 1

1.1 SUMMARY 1

1.2 CONCLUSIONS 1

$\begin{array}{lll}\text { 1.2.1 } & \text { Design Options } & 1 \\ 1.2 .2 & \text { Temperature Control } & 2\end{array}$

$\begin{array}{lll}2.0 & \text { INTRODUCTION N } & 3\end{array}$

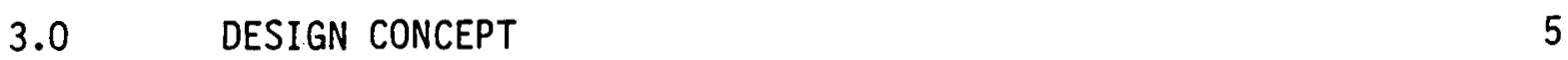

3.1 DESIGN REQUIREMENTS

3.2 TEST MODULE CONCEPT

$\begin{array}{lll}4.0 & \text { THERMAL CONTROL SYSTEMS } & 9\end{array}$

$\begin{array}{lll}5.0 & \text { RESULTS OF THERMAL ANALYSIS } & 15\end{array}$

5.1 THERMAL CALCULATIONS 15

5.2 BULK COOLANT CALCULATIONS $\quad 15$

5.3 THERMAL CONTROL GAS GAP SIZES 17

5.4 TEST TEMPERATURE VERSUS GAS GAP SIZE

$\begin{array}{lll}6.0 & \text { POSITIONER DESIGN CONCEPT } & 21\end{array}$

$\begin{array}{lll}7.0 & \text { REFERENCES } & 23\end{array}$

APPENDIX A NEUTRON HEATING DATA FOR VTA-2 THERMAL CALCULATIONS

A-1

APPENDIX B EFFECTS OF SIMPLIFYING ASSUMPTIONS ON TEST TEMPERATURES

B-1 


\section{FIGURES}

$\underline{\text { Figure }}$

1 VTA-2 Test Module 7

2 VTA-2 Schematic of Open-Loop Thermal Control System 10

3 VTA-2 Schematic of Closed-Loop Thermal Control System 12

$4 \quad$ Gap Size Versus Test Temperature Inside NaK-Bonded Test Chambers for Open Nitrogen Bulk Coolant System

$5 \quad$ Gap Size Versus Test Temperature Inside Nak-Bonded Center Test Chamber for Closed Nitrogen Bulk Coolant System 20

6 VTA-2 Positioner Concept

\section{TABLES}

Table

Page

1 Bulk Coolant Requirements

16

2

Thermal Control Gap Size Requirements

18 
1.0 SUMMARY AND CONCLUSIONS

1.1 SUMMARY

This report describes the conceptual design of Vertical Test Assembly 2 (VTA-2) with emphas is on the thermal design of the test system. VTA-2 is similar in structure to VTA-I and is composed of a test module, a test stalk, and a shield plug with positioner. VTA-2 is designed for irradiation of fusion material specimens at any desired temperature with in the range of $100^{\circ}$ to $650^{\circ} \mathrm{C}$. It will be located directly behind the VTA-1, which is positioned directly in front of the Fusion Materials Irradiation Test (FMIT) Facility's lithium target. A positioner concept is also presented but is not dimensionally defined.

An overall description of the VTA-1 and VTA-2, including nuclear characteristics within these modules and the ir interface requirements with the FMIT Facility, is given in Reference 1. Mechanical design details of the module, the test stalk or the shield plug with positioner are not included in this report.

\section{$1.2 \quad$ CONCLUSIONS}

\subsubsection{Design Options}

The design concept provides several options for achieving the required test temperatures of $100^{\circ} \mathrm{C}$ to $650^{\circ} \mathrm{C}$. These options are: 


\section{NaK-Bonded Chambers:}

- Temperatures below $460^{\circ} \mathrm{C}$ can be achieved by controlled gas gaps that conduct heat to an open- or closed-loop coolant system (nitrogen, helium or water).

- Temperatures above $460^{\circ} \mathrm{C}$ require in addition to the gas gaps:

-- Heating of the NaK bond for the open-loop coolant system (nitrogen)

-- Heating of the NaK bond or the loop coolant (or a combination of both) for the closed-loop coolant system (nitrogen or helium)

Weeper Chambers:

- Temperatures of $100^{\circ} \mathrm{C}$ can be achieved with an open-loop nitrogen coolant system or with a closed-loop water coolant system.

- Any desired temperature between $100^{\circ} \mathrm{C}$ and $650^{\circ} \mathrm{C}$ can be achieved by external heating of a closed-loop coolant system (nitrogen or helium); but, this temperature then represents the minimum temperature at which a companion Nak-bonded test can be operated in the same test module.

\subsubsection{Temperature Control}

The setpoint control accuracy and the temperature variation with in chambers have not been determined; however, experience with similar designs suggests that the required temperature control accuracy can be attained. 


\section{$2.0 \quad$ INTRODUCTION}

The proposed test module concept consists of a rectangular box-like structure with a capacity to accept three test chambers. These test chambers are surrounded by a flowing coolant that serves as a heat sink. Two types of chambers filled with fusion materials test specimens can be inserted into the test module. The first type, referred to as a NaK-bonded chamber, will contain specimens immersed in a NaK alloy. The NaK will serve as the thermal conducting media between the specimens and the chamber walls. The chamber walls are separated from the flowing coolant by a gas gap. The second type, referred to as a "weeper" chamber, will be provided with holes so that the spec imens contained in it will be directly cooled by flowing coolant.

This flowing coolant can be an open- or closed-loop system. The open loop draws nitrogen from the test ce11, blows it through the test module, and returns it to the test ce11. The closed loop provides a completely independent coolant circuit. 


\subsection{DESIGN REQUIREMENTS}

The following fusion materials test program design requirements were used as a bas is for development of the test module concept:

- VTA-2 shall provide for simultaneous irradiation of three chambers with each chamber having nominal dimensions of:

-- $5 \mathrm{~cm}$ wide horizontal $(x)$

-- $\quad 15 \mathrm{~cm}$ deep along beam axis (Z)

-- $20 \mathrm{~cm}$ high vertical (Y)

- Each chamber shall have independent temperature control with a temperature range with in each chamber of $100^{\circ}$ to $650^{\circ} \mathrm{C}$.

-- Setpoint control accuracy $\pm 10^{\circ} \mathrm{C}$

-- Calculated temperature variation with in chamber $\leq 10^{\circ}$

- VTA-2 shall have a min imum design lifetime under in-cell operating conditions of 1 full-power year.

- VTA-2 shall be capable of undergoing reconstitution with previously irradiated specimens.

- VTA-2 shall be capable of being positioned behind VTA-1 to with in $\pm 2 \mathrm{~mm}$ in the $X$ and $Y$ directions and to with in $\pm 1 \mathrm{~mm}$ in the $\dot{z}$ direction. 
The test module concept shown in Figure 1 consists of a rectangular stainless steel container divided by four walls into three test chambers. Rapid assembly, disassembly, and versatility are emphasized to accommodate a wide range of structural alloy specimens as well as special-purpose fusion materials such as ceramics. Test chamber pockets are sized to accept a $5-\mathrm{cm}$ wide $\times 15-\mathrm{cm}$ long $\times 20-\mathrm{cm}$ high test chamber. Test chambers are fastened to a common test module flange that seals the test pockets when the test chambers are inserted into the test module. The removable seal flange arrangement also provides for efficient test specimen removal and reconstitution after irradiation. Coolant inlet and outlet pipes and lower and upper coolant plenums serve to direct bulk coolant through the walls separating the pockets and/or through the bottom and top of each pocket. This coolant system provides a common heat sink for all three test chambers. This design allows the experimenter considerable versatility in the means of attaining the required test temperature.

Two basic types of test chambers (see Figure 1) are interchangeable and can be used in any of the three pockets. The first type will contain specimens immersed in NaK and will be used for high-temperature isothermal testing. NaK was chosen because it has high-thermal conductance and is liquid at ambient laboratory temperatures. Sodium can also be used as a heat transfer media. However, sodium changes phase and volume at $98^{\circ} \mathrm{C}$, and this must be considered in design and operation.

All outside chamber walls will be thermally insulated except for the side walls, which will be designed to provide a predetermined static gas gap between it and the cooled pocket wall. In the center position, both side walls will be gas gapped; in an outer position only the inward faring side wail will be gas gapped. This type of capsule will provide primary temperature control by adjustment of gas gap size and gas composition to balance heat removal with neutron heat generation. Additional specimen temperature control can be provided for the highest temperatures by 


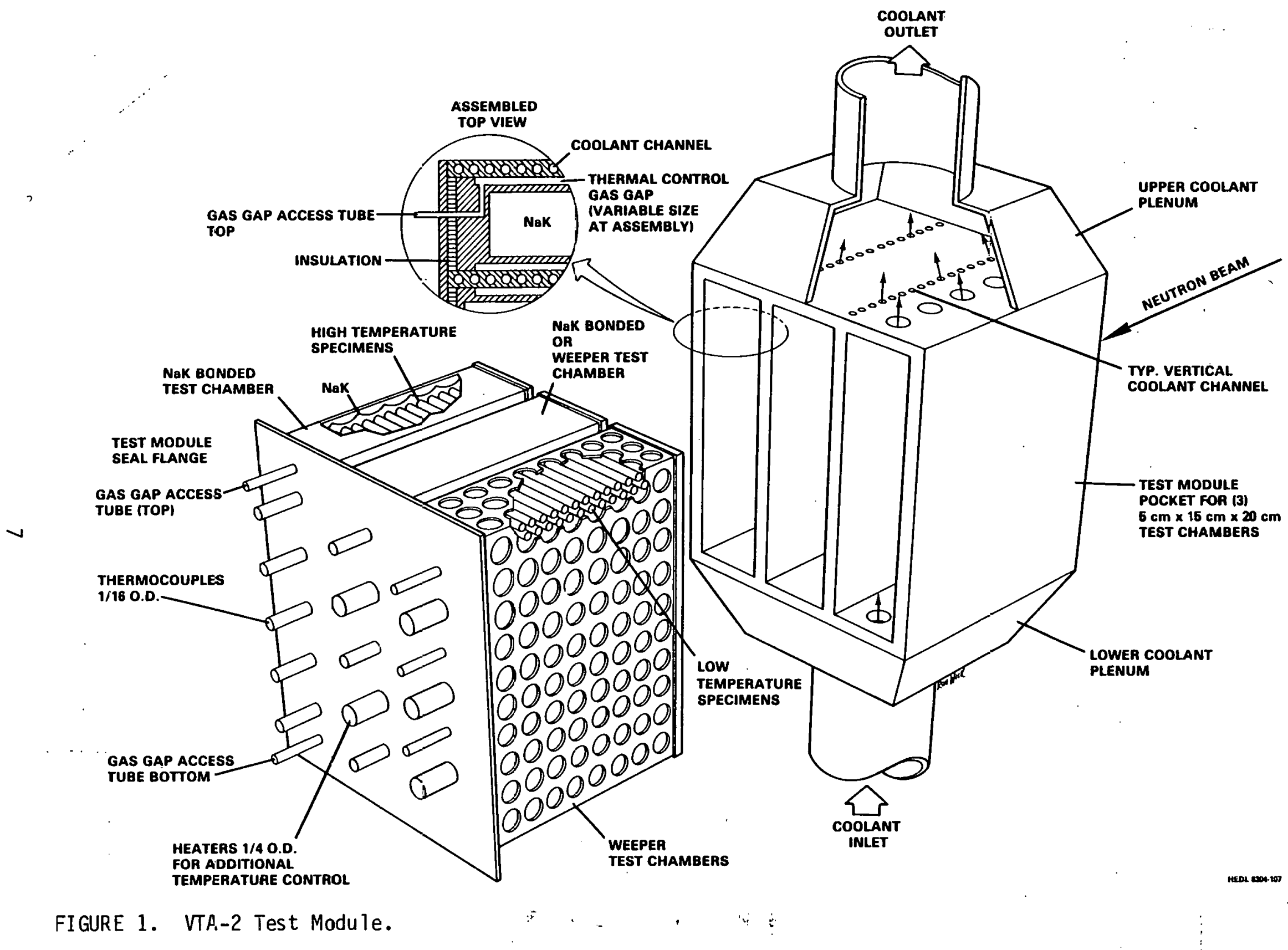


immersion heaters located inside the NaK-filled test chamber and/or by heating the bulk coolant systems.

The second type, called a weeper test chamber, will be provided with holes so that the specimens will be directly cooled by the flowing coolant. These chambers will be designed to support specimens in an easily accessible open cage. In these chambers, the spec imen temperature will be controlled by the temperature of the coolant. This coolant may be inert gas or water that is limited to low-temperature operation. Bulk temperature may be externally controlled by a heater in the common coolant loop.

Both types of test chambers are instrumented with thermocouples to provide on-line test specimen temperature measuring capability. 
At the outset it was decided that thermal control must be achieved in a reliable, straightforward way compatible with the current test cell/service cell and the VTA-1 designs.

The temperature control system must be capable of independently regulating the temperature of each test chamber with in the range of $100^{\circ}$ to $650^{\circ} \mathrm{C}$. In order to minimize heat transfer and thermal stresses, it was assumed that maximum temperature differences between adjacent test chambers wi 11 be limited to $150^{\circ} \mathrm{C}$. For example, a module could operate with test chambers at $600^{\circ} \mathrm{C}, 450^{\circ} \mathrm{C}$, and $300^{\circ} \mathrm{C}$. It was a 150 assumed, based upon fabrication and operating experience, that the minimum practical gas gap width is 0.005 inches, and the maximum gas gap width is 0.050 inches.

The proposed thermal control concepts involve one or a combination of the following: a temperature-controlled flowing coolant to remove neutrondeposited heat, static gas gaps to control individual test chamber temperatures, and heaters to adjust the internal test chamber power generation level.

The gases considered were either nitrogen or helium. Nitrogen is inexpensive, has low-neutron activation, and is the reference FMIT test cell atmosphere. The VTA-2 test module is located in the test cell and is, therefore, surrounded by a nitrogen atmosphere. The cell nitrogen can be diverted into the VTA-2 tubing to form an open-loop bulk coolant system. Figure 2 is a simplified schematic of the open system. In this system, nitrogen is drawn by a centrifugal blower from the test cell and is blown through the VTA-2 piping in the shield plug. This blower, located above the shield plug under the service dome (see Figure 3 of Reference 1), forces nitrogen down through a return pipe in the shield plug which, is connected to the VTA-2 test module. The nitrogen cools the test module side walls and/or the pocket for weeper tests and exits the test module at the top. Nitrogen then returns to the test cell. 


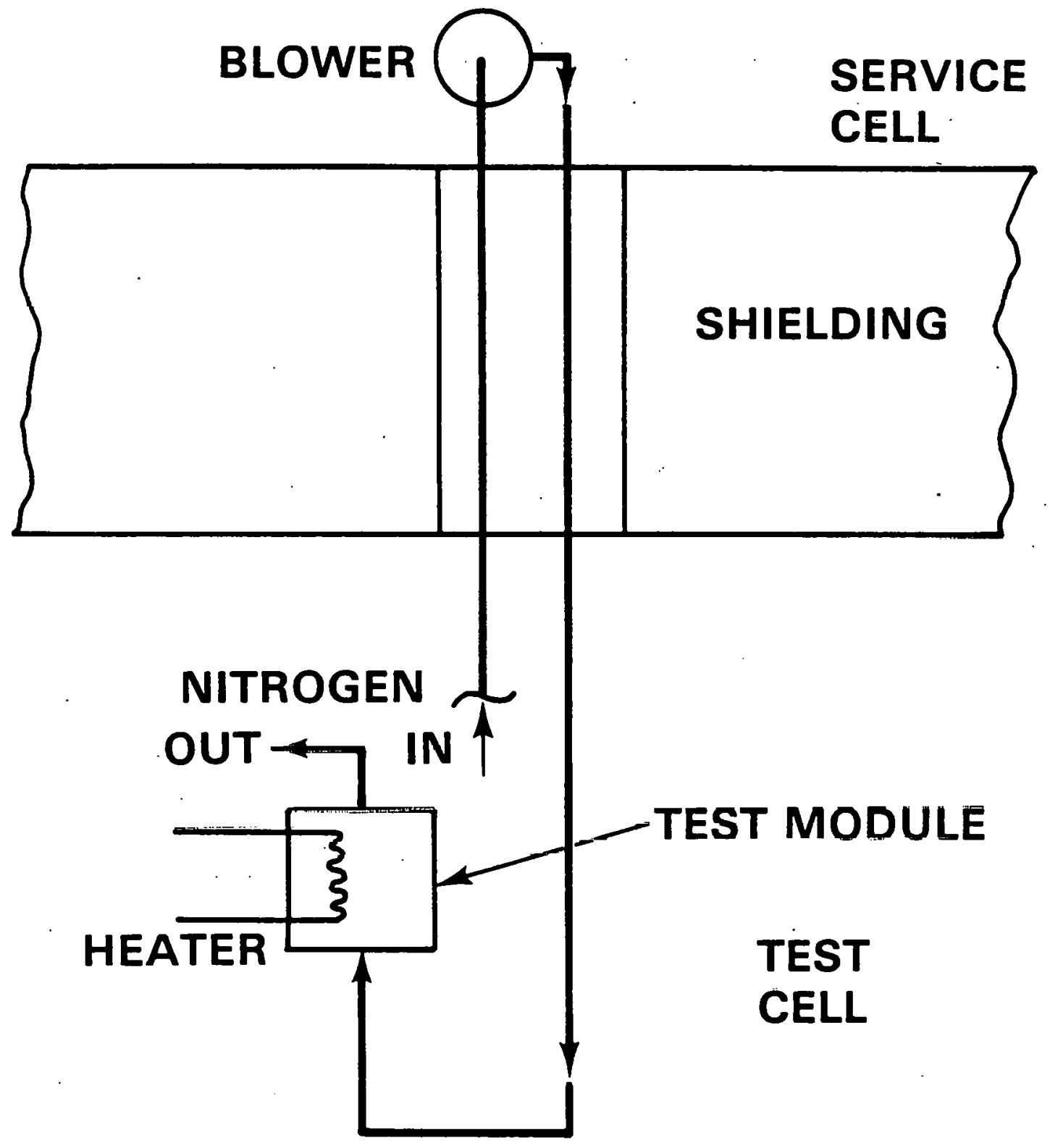

HEDL 8306-016.2

FIGURE 2. VTA-2 Schematic of Open-Loop Thermal Control System. 
Advantages of this system are:

- It does not require a separate heat exchanger to cool the nitrogen (cooling provided by test cell cooling system).

- It is a low-pressure system requiring only a low head $(\Delta P)$ blower.

Disadvantages of this system are:

- It limits the weeper test chamber temperature to the maximum test cell gas temperature of approximately $100^{\circ} \mathrm{C}$.*

- It will be shown later that the upper temperature limit of a NaKbonded center test chamber without additional electrical heating, using a 0.050 in. maximum gas gap, is approximately $460^{\circ} \mathrm{C}$.

- The $650^{\circ} \mathrm{C}$ test temperature can be attained by adding approximately 500 watts of electric heat to the NaK-bonded test chamber.

The closed-1oop coolant system can be designed to atta in the $650^{\circ} \mathrm{C}$ without requiring heaters in the test chamber. A schematic of a closed-loop system with independent external temperature control is shown in Figure 3 . The closed loop has the advantage of controlling the temperature of the circulating gas independent of the test cell environment. The coolant can be water, helium, or nitrogen. Water and helium have the advantage of better thermal heat transport properties than nitrogen, and hence smaller mass flow rates are required. However, a larger volumetric flow rate of helium is required than nitrogen because of its lower density. In the case of water, the upper temperature limit without significant pressurization is $100^{\circ} \mathrm{C}$. This represents approximately the same bulk coolant temperature as for the open nitrogen system. Therefore, for a water heat sink, heaters are also required inside the NaK-bonded test chamber to attain the $650^{\circ}$ test specimen temperature.

*This represents $75^{\circ} \mathrm{C}$ cell temperature pius $25^{\circ} \mathrm{C}$ temperature rise through the test module. 


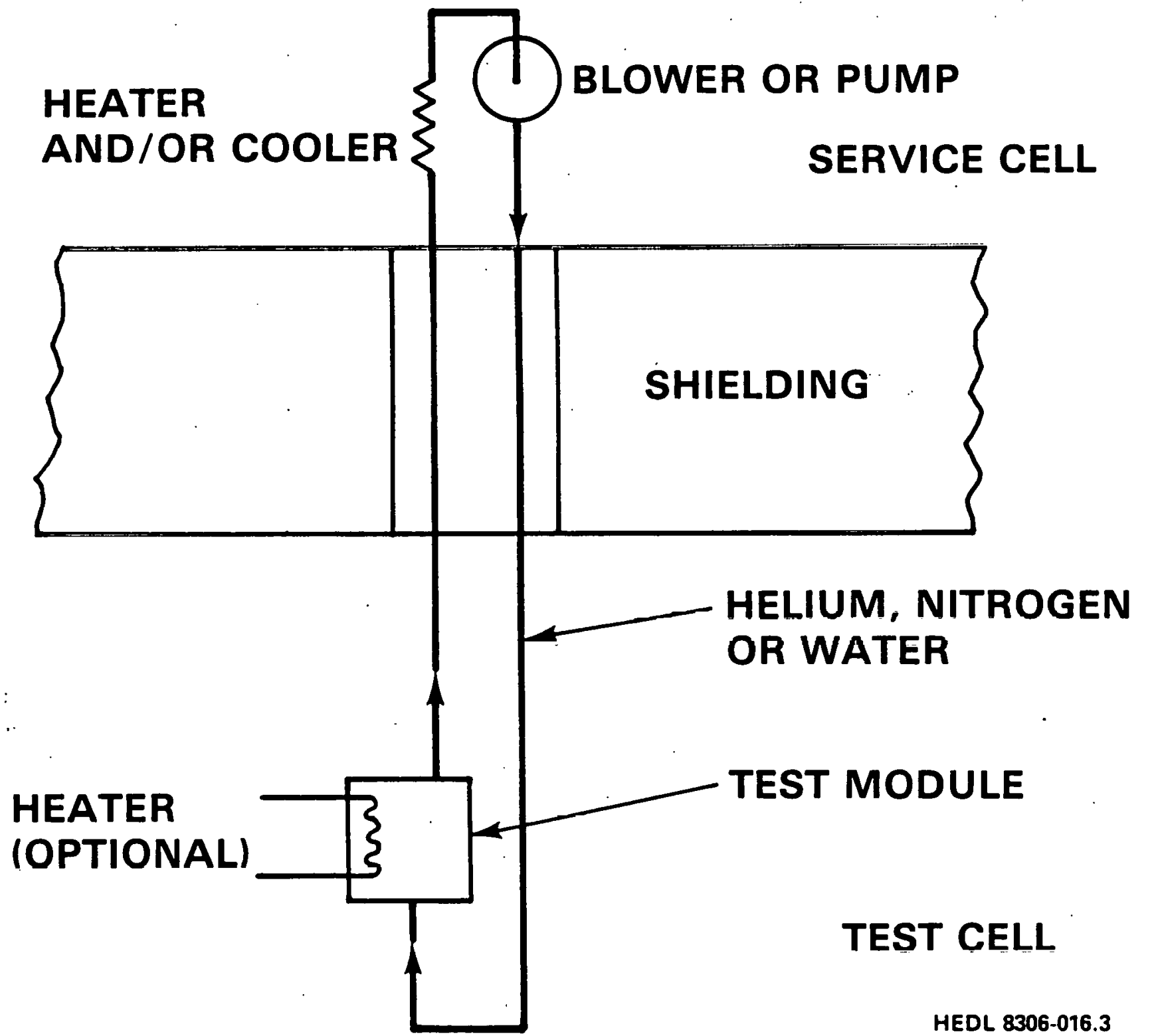

FIGURE 3. VTA-2 Schematic of Closed-Loop Themal Control System. 
Helium or nitrogen can be maintained at any desired temperature required to attain test temperature. For a $6500 \mathrm{C}$ NaK-bonded test chamber temperature, the helium or nitrogen bulk temperature must be approximately $3000 \mathrm{C}$. Weeper test chamber temperatures up to $6500 \mathrm{C}$ are obtained by adjusting the bulk gas coolant loop temperature to the desired test temperature. 
$5.0 \quad$ RESULTS OF THERMAL ANALYSIS

5.1 THERMAL CALCULATIONS

The following data were used in the calculations:

- Neutron heating data calculated for VTA-2 (see Appendix A and Reference 3)

-- Heating in each outside chamber 590 watts

-- Heating in center chamber $\quad 844$ watts

-- TOTAL $(2 \times 598+844) .2040$ watts

- Bulk coolant calculations assume no heat loss or gain except at desired heat transfer surfaces

- Conduction calculations are one dimensional; they assume that all surfaces except those selected for heat transfer are perfectly insulated

- Heat transport properties for helium, nitrogen, and water are from Reference 2

\section{$5.2 \quad$ BULK COOLANT CALCULATIONS}

Table 1 presents the assumptions and results of the bulk coolant system flow rate and pipe size calculations. Results show that the pressurized closedloop system requires a smaller pipe size than the open-loop system. It also indicates that helium requires larger coolant lines than $n i t r o g e n$, and water requires the smallest pipe size. 
TABLE 1

BULK COOLANT REQU IREMENTS

$\begin{array}{llr}\text { Assumptions: } & \text { Temperature (out let): } & 100{ }^{\circ} \mathrm{C} \\ & \text { Temperature (in let): } & 750 \mathrm{C} \\ & \Delta \mathrm{T}: & 250 \mathrm{C} \\ & \text { Pressure (open } \mathrm{N}_{2} \text { systems): } & 1 \mathrm{~atm} \\ & \text { Pressure (closed systems): } & 3 \mathrm{~atm} \\ & \text { Velocity in Piping (gas): } & 100 \mathrm{ft} / \mathrm{s} \\ & & 10 \mathrm{ft} / \mathrm{s}\end{array}$

Results:

\begin{tabular}{lccc}
\multicolumn{1}{c}{ Coolant } & $\begin{array}{c}\text { Flow Rate } \\
\left(\mathrm{ft}^{3} / \mathrm{min}\right)^{*}\end{array}$ & $\begin{array}{c}\text { Pipe Size } \\
\text { (in.) }\end{array}$ \\
$\mathrm{N}_{2}$ (open system) & $166.0(1 \mathrm{~atm})$ & $2-1 / 4$ \\
$\mathrm{~N}_{2}$ (closed system) & $55.3(3 \mathrm{~atm})$ & $1-1 / 4$ \\
He lium (closed system) & $79.4(3 \mathrm{~atm})$ & $1-1 / 2$ \\
Water (closed system) & $0.308(\mathrm{gpm})$ & $1 / 4$
\end{tabular}

*Volumetric rate at pressure and temperature conditions of flowing gas. 


\subsection{THERMAL CONTROL GAS GAP SIZES}

Table 2 presents the assumptions and results of the thermal control gas gap sizes and compositions required to attain various temperature ranges inside NaK-bonded test chambers. Appendix $B$ shows the effects of the simplifying assumptions on predicted test temperatures.

Values are first presented for the center and outside test chambers without supplemental electrical heating. Next, the increase in temperature range resulting from the addition of 500 watts of electrical heating to the inside of the center test chamber is shown. The outside test chamber requires approximately 50 watts of electrical heating to attain a $650^{\circ} \mathrm{C}$ temperature with a 50-mil nitrogen gas gap.

\subsection{TEST TEMPERATURE VERSUS GAS GAP SIZE}

Figure 4 shows the test temperatures attained for various gas gap sizes ins ide a NaK-bonded center chamber and an outside test chamber without supplemental electrical heating. The difference in temperature between using helium and nitrogen in the gas gap is indicated. Figure 4 is an open-loop nitrogen bulk coolant system (nitrogen taken from and returned to the test ce 11).

Figure 5 shows the test temperatures attained for various gap sizes inside a NaK-bonded center test chamber. It shows the effect on temperature of externally heating the bulk nitrogen coolant system to $300^{\circ} \mathrm{C}$ or of supplying 500 watts of electrical heat to the test chamber.

Figures 4 and 5 show that a proper combination of gas gap size and composition, bulk coolant, or internal test chamber heating will provide the required test temperature range of $100^{\circ} \mathrm{C}$ to $650^{\circ} \mathrm{C}$ ins ide NaK-bonded test chambers.

The required test temperature range of 100 to $650^{\circ} \mathrm{C}$ can be attained inside weeper test chambers by adjusting the bulk coolant temperature of a closedloop system to the desired temperature level. 
TABLE 2

THERMAL CONTROL GAS GAP SIZE REQUIREMENTS -

Assumptions:

- Bulk coolant outlet temperature: $100^{\circ} \mathrm{C}$

- Center test chamber: top and bottom, front and back are perfectly insulated; both sides are cooled.

- Outer test chambers: top and bottom, front and back, and outboard side are perfectly insulated; inboard side is cooled.

- Allowable gap size: 5-50 mil*

- Gap gas: 1 atm at $400^{\circ} \mathrm{C}$

- $\Delta T s$ due to gas $f i l m$, chamber walls on Nak bond are neglected. Gas Gap $\Delta T\left({ }^{\circ} \mathrm{C} / \mathrm{mil}\right)$

\begin{tabular}{|c|c|c|c|}
\hline Gas & $\begin{array}{r}\text { Cente } \\
(844 \text { W) }\end{array}$ & $\begin{array}{l}\text { hamber } \\
(1344 W)\end{array}$ & $\begin{array}{l}\text { Outs ide Chamber } \\
(598 \mathrm{~W}) \\
\end{array}$ \\
\hline Heli um & 1.344 & 2.13 & 1.883 \\
\hline Nitrogen & 7.28 & 11.58 & 10.17 \\
\hline
\end{tabular}

Attainable Range of Temperatures $\left({ }^{\circ} \mathrm{C}\right)$ Without Additional Heating

\begin{tabular}{|c|c|c|c|c|}
\hline \multirow[b]{2}{*}{ Gas } & \multicolumn{2}{|c|}{ Center Chamber } & \multicolumn{2}{|c|}{ Outside Chamber } \\
\hline & $\begin{array}{c}\text { Gap Range } \\
\text { (mil) }\end{array}$ & $\begin{array}{c}\text { Temperature } \\
\left({ }^{\circ} \mathrm{C}\right)\end{array}$ & $\begin{array}{c}\text { Gap Range } \\
\text { (mil) }\end{array}$ & $\begin{array}{c}\text { Temperature } \\
\left({ }^{\circ} \mathrm{C}\right)\end{array}$ \\
\hline Helium & $5-50$ & $107-167$ & $5-48$ & $109-190$ \\
\hline Nitrogen & $9-50$ & $168-464$ & $9-50$ & $191-609$ \\
\hline
\end{tabular}

Attainable Range of Temperatures ( $\left.{ }^{\circ} \mathrm{C}\right)$ with $500-W$ Electrical Heating

\begin{tabular}{|c|c|c|}
\hline Gas & $\begin{array}{c}\text { Gap Range } \\
(\text { mi }) \\
\end{array}$ & $\begin{array}{l}\text { Temperature } \\
\left(\mathrm{O}^{\mathrm{C}}\right)\end{array}$ \\
\hline Hel & $5-50$ & $111-207$ \\
\hline Nitrogen & $9-50$ & $204-679$ \\
\hline
\end{tabular}

$\star 1 \mathrm{mil}=0.001$ inches. 


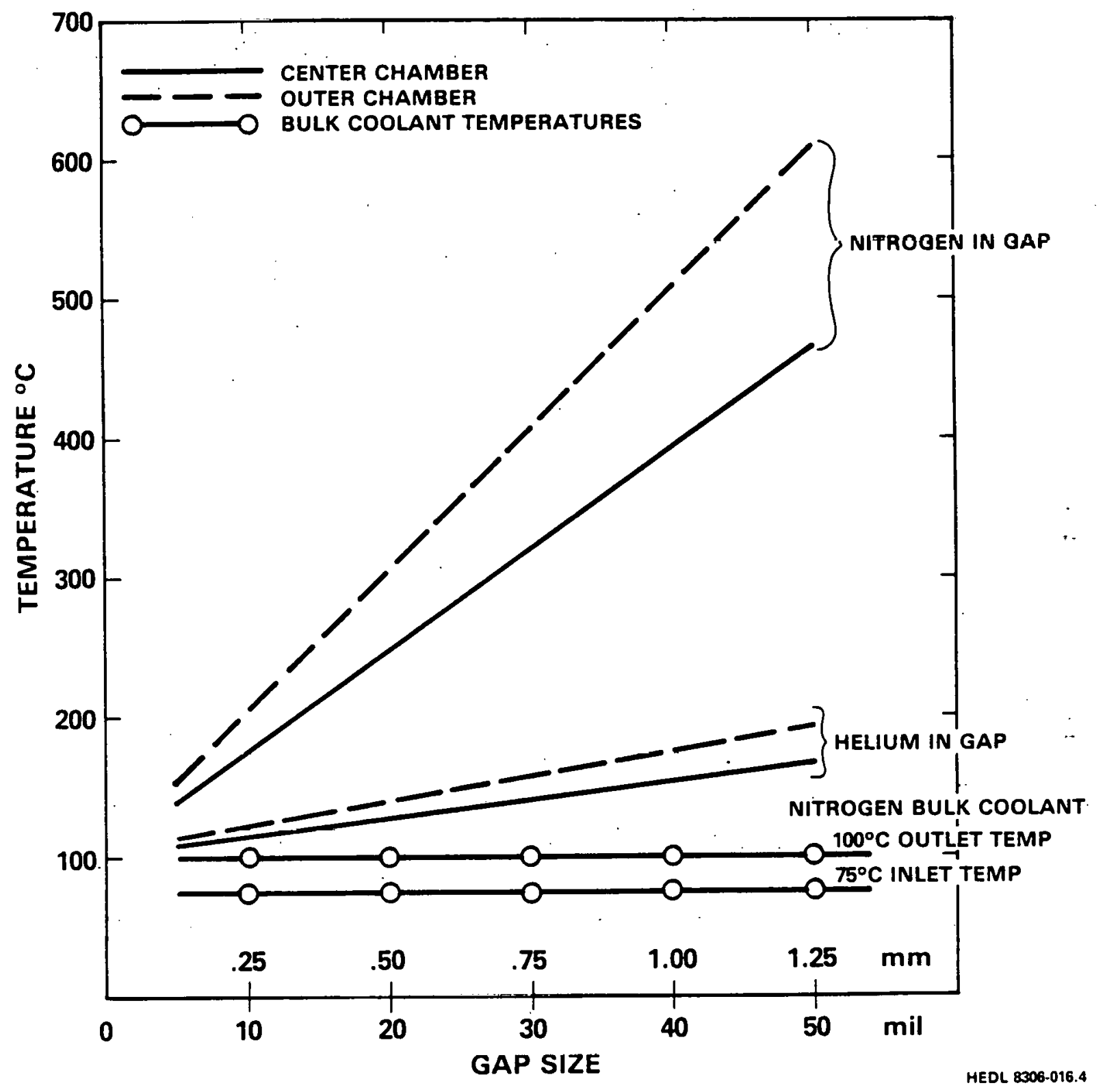

FIGURE 4. Gap Size Versus Test Temperature Inside NaK-Bonded Test Chambers for Open Nitrogen Bulk Coolant System. 


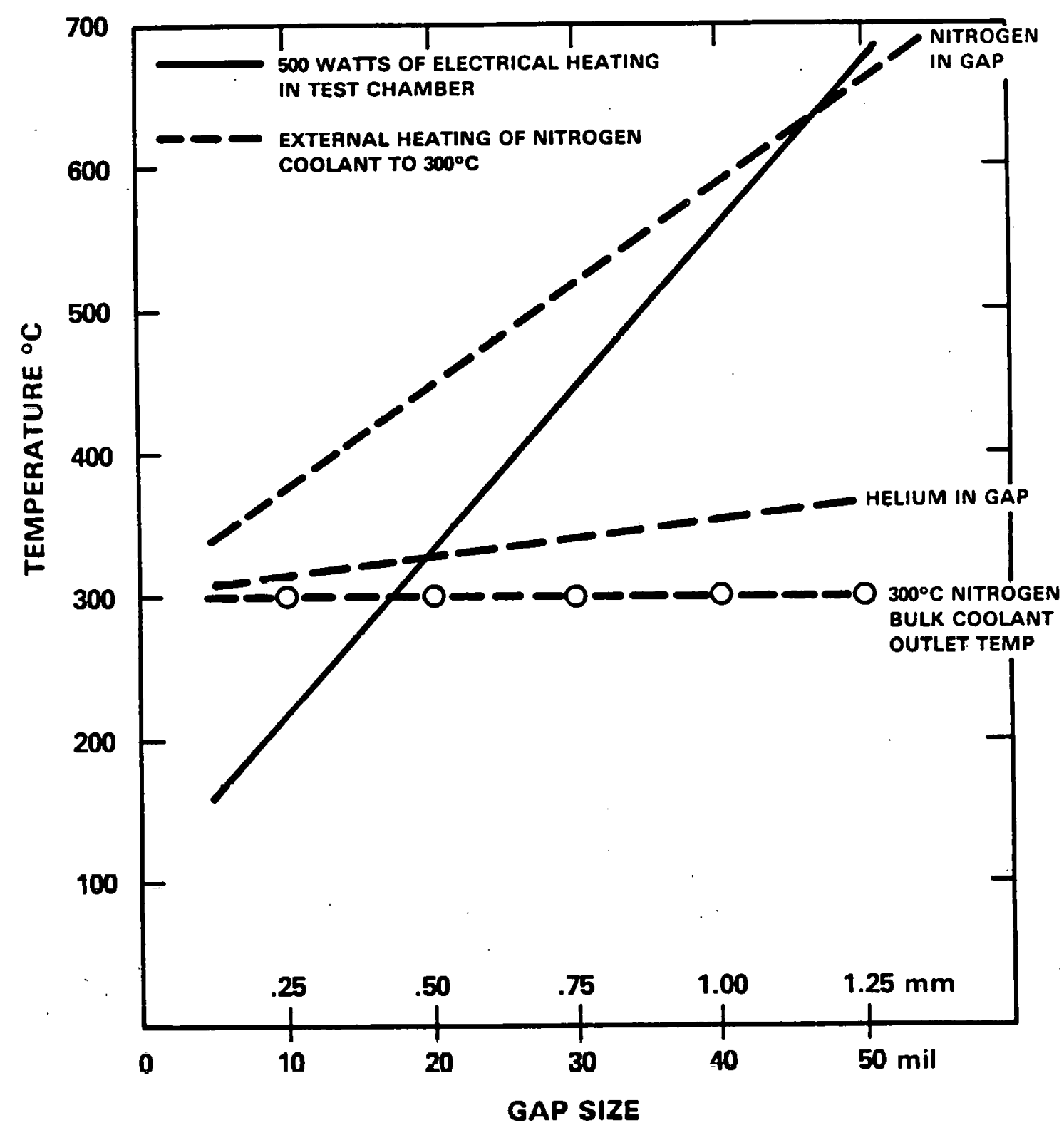

HEDL 8306-161 .1

FIGURE 5. Gap Size Versus Test Temperature Inside NaK-Bonded Center Test Chamber for Closed Nitrogen Bulk Coolant System. 
A positioner is required to accurately locate the VTA-2 module behind the VTA-1 test module in the optimum neutron flux field. VTA-2 positioning accuracy requirements are somewhat less than for VTA-1; however, additiona 1 complexity is introduced because the VTA-2 shield plug position is located approximately 14 inches from the center of the neutron beam Z-axis. (See Figure 4 of Reference 1.) The positioner requires a mechanism for translating the VTA-2 module sideways along the $X$-axis to the neutron beam centerline. In addition, it must. move VTA-2 forward in the $Z$ direction so it contacts* the back of VTA-1. It must also locate the center of the test module on the vertical $\mathrm{Y}$-axis beam centerline.

A simplified diagram of a concept for accomplishing these requirements is shown in Figure 6 . Th is concept utilizes a parallelogram support structure to articulate the test module in the horizontal $X$ direction. The $Z$ direction adjustment will be made by sliding the support structure towards VTA-1 using a sliding bushing (Thompson rails). The vertical $Y$ position will be established by design so that the test module will be in the correct vertical position when the $X$ and $Z$ motions have been completed. The positioner requires flexible bulk coolant lines between the test module and the shield plug to provide for compliance during positioner adjustment.

*It may be designed to provide a slight amount of standoff from VTA-1. 


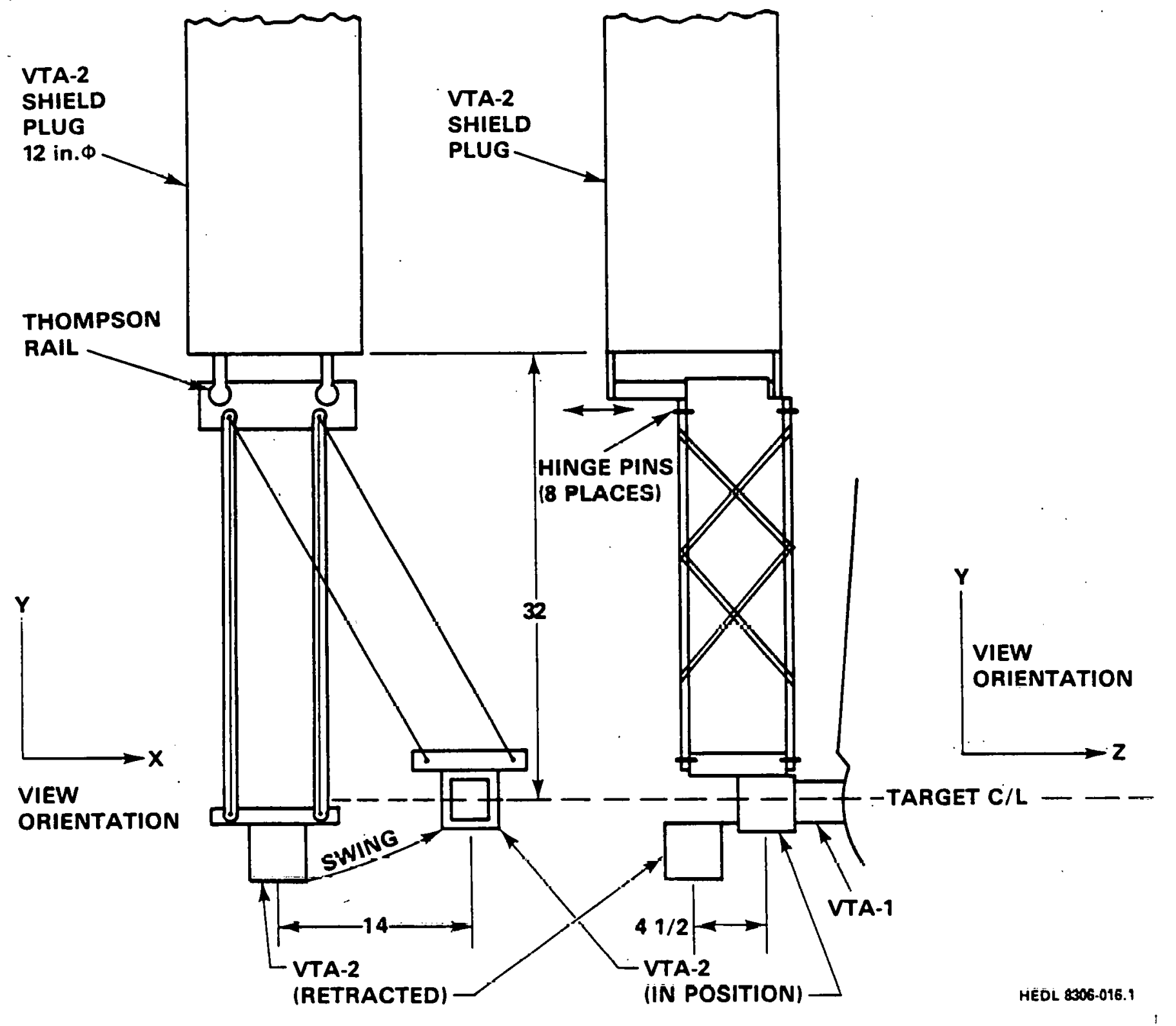

FIGURE 6. VTA-2 Positioner Concept. 


\section{$7.0 \quad$ REFERENCES}

1. E. K. Opperman, Fusion Materials Irradiation Test Facility - Experimental Capabilities and Test Matrix, HEDL-TME 81-45, Hanford Engineering Development Laboratory, Richland, WA, January 1982.

2. H. E. Etherington, "Physical Properties of Heat Transport Mediums,". Nuclear Engineering Handbook, 1st ed., Sec. 9-1, 1958.

3. L. L. Carter, A. B. Wilcox and D. E. Hegberg, "Nuclear Heat Deposition for a Fusion-Like Neutron Environment," Trans. Am. Nucl. Soc. 39, p. 784, 1981 . 
A P P E D I X A

NEUTRON HEATING DATA FOR

VTA-2 THERMAL CALCULATIONS

$A-1 / 2$ 


\section{NEUTRON HEATING DATA FOR VTA-2 THERMAL CALCULATIONS}

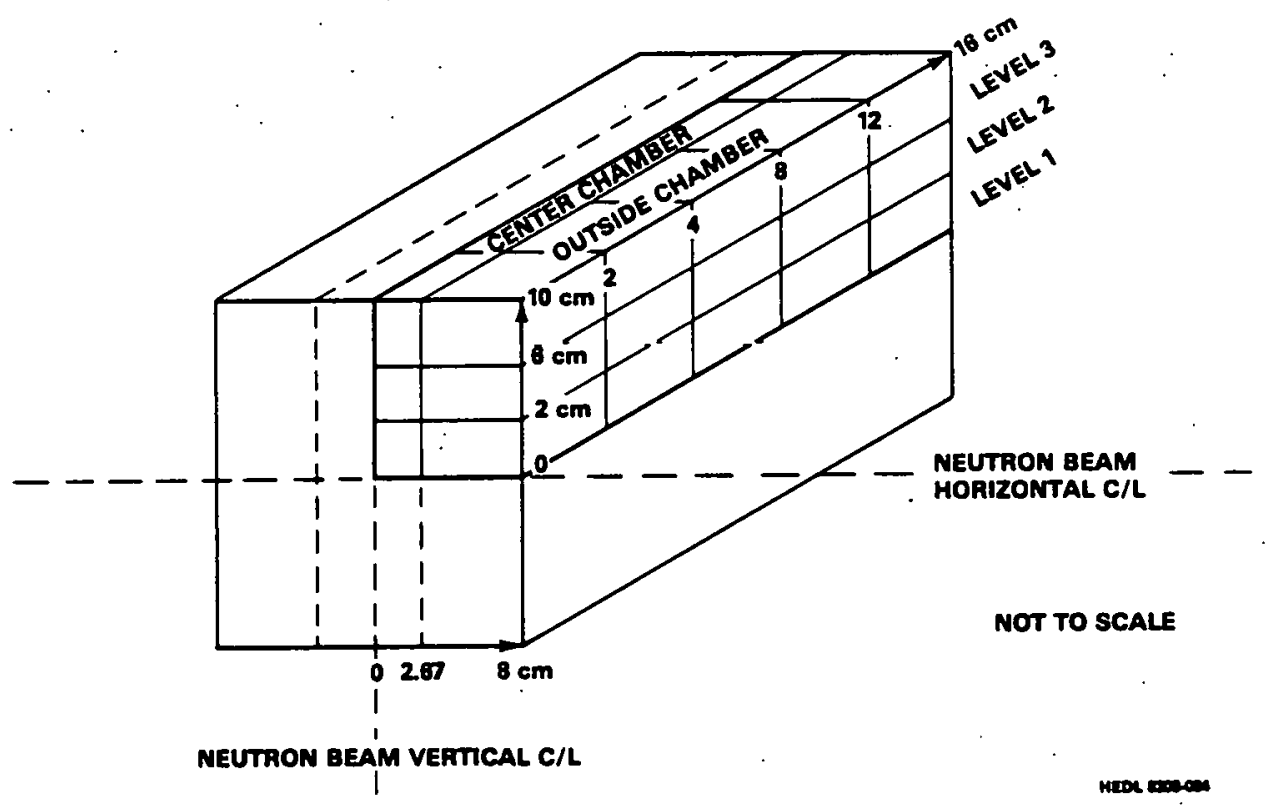

FIGURE A1. Location of VTA-2 Neutron Heating Zones.

\section{TABLE Al}

HEATING RATES* IN NEUTRON ZONES

Front to Back Location.

$0-2$

$2-4$

$4-8$

$8-12$

$12-16$

TOTAL

\begin{tabular}{|c|c|c|}
\hline \multicolumn{3}{|c|}{$\frac{\text { Center Chamber }}{\text { Leve }}$} \\
\hline 1 & 2 & 3 \\
\hline $\begin{array}{rl}22 & \\
16 & 1 / 3 \\
20 & 1 / 3 \\
11 & 2 / 3 \\
6 & 2 / 3\end{array}$ & $\begin{array}{ll}24 & 2 / 3 \\
20 & 2 / 3 \\
28 & 2 / 3 \\
17 & 1 / 3 \\
10 & 2 / 3\end{array}$ & $\begin{array}{ll}6 & 1 / 3 \\
5 & 1 / 3 \\
9 & 2 / 3 \\
6 & 2 / 3 \\
4 & \end{array}$ \\
\hline
\end{tabular}

$211 \times 4=844$ watts

\begin{tabular}{|c|c|c|}
\hline & $\frac{\text { ide Cha }}{\text { Level }}$ & ber \\
\hline 1 & 2 & 3 \\
\hline $\begin{array}{ll}23 & \\
19 & 2 / 3 \\
26 & 2 / 3 \\
16 & 1 / 3 \\
10 & 1 / 3\end{array}$ & $\begin{array}{ll}34 & 1 / 3 \\
29 & 1 / 3 \\
42 & 1 / 3 \\
28 & 2 / 3 \\
16 & 1 / 3\end{array}$ & $\begin{array}{rl}9 & 2 / 3 \\
9 & 2 / 3 \\
15 & 1 / 3 \\
10 & 1 / 3 \\
7 & \end{array}$ \\
\hline
\end{tabular}

$299 \times 2=598$ watts

*Heating rates are for one symmetric quadrant. Numbers must be multiplied by 4 for center chamber, by 2 for outside chamber. 


$$
\text { A P P E D I X B }
$$

EFFECTS OF SIMPLIFYING ASSUMPTIONS

ON TEST TEMPERATURES

$$
B-1 / 2
$$




\section{EFFECTS OF SIMPLIFYING ASSUMPTIONS ON TEST TEMPERATURES}

The following factors were omitted in the calculation of test temperatures. A sumary of the factors that tend to increase (+) or decrease (-) test temperatures, including an estimate of the effect are given below:

\section{Factor}

Film drop (coo
$\Delta T$ metal wall

$\Delta T$ NaK-filled chamber

$\Delta T$ conduction heat loss from $0.25-i n$.

Nak-insulated walls

Net change
Equation

$\Delta T=\frac{Q}{A h_{f}}$

$\Delta T=\frac{Q}{A}\left(\frac{L}{k}\right)$

$\Delta T=\frac{0 r \ell^{\star^{2}}}{2 k}$

$\Delta T \propto \frac{Q}{A}\left(\frac{L}{k}\right)$

$-11$

$-107$

$+25$

$+34$

$+4$

$+9$
Resulting Temperature $\left({ }^{\circ} \mathrm{C}\right)$ Increase ( + ) or Decrease (-) Center Chamber Outside Chamber

$+21^{\circ} \mathrm{C}$

$-60^{\circ} \mathrm{C}$

Where:'

$$
\begin{aligned}
& \ell *=0.082 \mathrm{ft} \text { for center chamber } \\
& 0.164 \mathrm{ft} \text { for nutside chamber } \\
& \Delta T=\text { Temperature difference }\left({ }^{\circ} \mathrm{C}\right) \\
& \frac{Q}{A}=\text { Heat flux }\left(B t u / h \cdot f t^{2}\right) \\
& h_{f}=\text { Heat transfer coefficient }\left(B t u / h^{\circ} \cdot t^{2 \cdot 0} F\right. \text { ) } \\
& L=\text { Thermal conduction length (thickness- } f t \text { ) } \\
& k=\text { Thermal conductance }\left(B t u / h \cdot \mathrm{ft}^{2 \cdot 0^{\circ}} \mathrm{F}\right) \\
& Q_{v}=\text { Volumetric heat generation }\left(B t u / h \cdot \mathrm{ft}^{3}\right. \text { ) }
\end{aligned}
$$




\section{Conclusions:}

- Center test chamber will operate $210 \mathrm{C}$ hotter than predicted by Figures 5 and 6 .

- Outside chamber will operate $600 \mathrm{C}$ cooler than predicted by Figure 5 .

- Allowance for the above factors must be made by design and operation of the experiments. 
$\underline{U C-20}$ (108)

DOE-RL /AMAR

Breeder Technology Division

FED-650B

JJ Keating, Director

DOE-HQ/Office of Fusion Energy

ER-70

Washington, DC 20515

FA Smidt Jr,

Program Division Director

HEDL (24)

$\begin{array}{ll}\text { RJ Burke } & \text { W/B-42 } \\ \text { AM Ermi } & \text { W/A-58 } \\ \text { JL Fuller } & \text { W/B-41 } \\ \text { JM Grover } & \text { W/A-105 } \\ \text { JW Hagan } & \text { W/B-43 } \\ \text { JJ Holmes } & \text { W/A-106 } \\ \text { VP Kelly } & \text { W/B-40 } \\ \text { NE Kenny } & \text { W/C-115 } \\ \text { WL Knecht } & \text { W/B-41 } \\ \text { SG Nightingale } & \text { W/A-106 }\end{array}$

MM Paxton

$W / A-64$

RW Powe 11

EJ Shen

$W / A-58$

JL Straalsund

$W / B-40$

$W / A-61$

JW Thornton

MA Vogel (2)

HH Yoskikawa

W/A-106

W/A-105

Central Files (3) $\quad W / C-125$

Publ Services (2) $\quad W / C-115$

Microfilm Services W/C-123 